\title{
Embracing Diversity: The Case of EquityRes, a Student Residence at Urban University
}

\author{
S. Vandeyar and A. M. Mohale
}

Faculty of Education, University of Pretoria, South Africa

KEYWORDS Diversity. Institutional Culture. Integration. Race. University Students

\begin{abstract}
Utilising a qualitative case study and the methodology of portraiture, this paper set out to explore how the institutional culture at EquityRes, a university student resident in South Africa, promoted interaction of culturally diverse students. Data capture included a mix of semi-structured interviews, field notes and a researcher journal. Data was analysed by means of the content analysis method. Theoretical moorings of this study were embedded in critical race theory and cosmopolitanism. Findings reveal that the design of living spaces, the consultative participatory management style and inclusive cultural and social activities at EquityRes, promoted equality and interaction of diverse students. The paper concludes by recognising that the transformation policies developed by EquityRes, not only recognised the significance of the construct of race, but were intent on curbing racial and cultural discrimination and embracing diversity. These polices were enacted in the lived experiences of diverse resident students and created opportunities for intercultural contact and meaningful interaction.
\end{abstract}

\section{INTRODUCTION}

The complexity of managing diversity is presently one of the most significant challenges faced by higher education institutions. The challenge lies in creating institutional cultures that genuinely respect and appreciate differences and diversity (HESA 2014). The literature reveals that universities are globally in a crisis. According to Bridgman and Murdoch (2008: 258), "The University is in a crisis over its crises”. Dissatisfaction with universities is not unique to South Africa. A research project that was undertaken by 25 researchers from 15 countries, including South Africa, revealed the extent of dissatisfaction regarding the lack of transformation at universities (Brennan et al. 2004:7). Butler-Adams’ (2015) aptly captures this sentiment in his study titled, "Is the decline and fall of South African universities looming?”

South African universities are still reeling from the effect of protest movements that gained momentum since October 2015 and continued

Address for correspondence:

Saloshna Vandeyar

Professor

Department of Humanities Education

Faculty of Education, University of Pretoria

Groenkloof Campus, Leyds Street,

Pretoria 0001, South Africa

Telephone: (012) 4202003

Fax: 012 420-563

E-mail: Saloshna.Vandeyar@up.ac.za into 2016. It is apparent that these protests have forever changed the landscape of tertiary education in South Africa. Protests were launched under the banner of the 'Fees Must Fall' campaign and represent the largest student movement since the 1976 Soweto riots (Lukhele 2015: 72). It is more than twenty years since the advent of democracy in South Africa and yet, no solution is evident for the plethora of challenges faced by the higher education sector in South Africa.

The recent protests were initially sparked by the University of the Witwatersrand announcing a 10.5 percent fee increase for 2016. By midOctober 2015 the protest that begun at the University of the Witwatersrand had spread to the University of Cape Town and Rhodes University. The 'Fees Must Fall' protest spread rapidly across the country and on 23 October 2015, ten thousand students gathered in Pretoria to make it clear that they were outraged that tertiary education was excluding the poor. "High tuition fees would effectively create a new kind of apartheid, forever separating the haves and havenots” (Lukhele 2015: 69).

Although it seems as if students were protesting about issues such as language and fees, the underlying causes run much deeper. In 1985, Bot (1985: 12) argued that repressive action by universities against protests would not be likely to quell protest while apartheid policies continue to apply both to education and the wider socio-political environment. In 2015, Jansen was 
convinced that the current protests were not about fees (Tswanya 2015). He argued that people should pay attention to, amongst other things, that at the core of the student protests is genuine progressive concerns about inequality and a lack of transformation and access to tertiary education. Lukhele (2015: 68) argues that South Africa's student uprising signals wider social upheaval and that although it seems as if the one million university students won the battle against an immediate increase in education fees, the larger war against economic inequality is far from over. Baloyi and Isaacs (2015) agree with the afore-mentioned authors that the protests are about more than tuition costs; they are also about the decolonization and transformation of higher education institutions as well as white dominance, patterns of thinking and the style and content of teaching.

South African universities with diverse student populations are microcosms of South African society. Universities thus have the potential to provide an environment that is welcoming to culturally diverse students; to share rich experiences brought from their diverse ethnic and cultural backgrounds (McLean 2000), and to create platforms for issues of tolerance, inclusion, access and structural inequalities to be addressed (Cross 2004). This implies that institutions have to create opportunities that will help students experience genuine racial integration and also encourage them to interact in meaningful ways (Gurin et al. 2004). It is thus important for institutions to go beyond the enrolment increments of particularly previously disadvantaged groups, because the achievement of simple numerical diversity does not guarantee interaction between diverse groups staying on the same campus (Gurin et al. 2004; Jansen 2015). This study focused on one student residence, namely, EquityRes at Urban University (UU).

Intervention to integrate residences came in the late 1990s at UU as a response to the practice of allocating black and white students to different residences. Residence traditions at UU were well established and valued. Resultantly, black students felt excluded by strong Afrikaner-orientated cultural practices and traditions (CHE 2010). However, UU has since mandated several changes which led to an improvement in residence interactions (CHE 2010). It is a requirement for every residence to have Black students among its leadership at UU. Black staff members were also recruited to occupy vacancies as heads of residences. UU structured policies that discouraged and forbade traditions that offended other cultures. The task team of the Council of Higher Education acknowledged that changing residence culture and tradition has significantly advanced residence transformation at UU. In order to celebrate diversity, residence activities were structured to facilitate greater interaction and understanding (CHE 2010). Accordingly this study asks: How does the institutional culture at EquityRes promote interaction of culturally diverse students?

\section{Integration of Diverse Students at University Residences}

A review of the voluminous international literature reveals a lack of integration between students of diverse races and cultural backgrounds at university residences (Antonio 2001; Breaux 2002). Some studies suggest that living arrangements in several university residences were seen as a way of segregating diverse students (Ward and Masgoret 2004; Brown 2009; Peacock and Harrison 2009; Thornton et al. 2010). Thornton et al. (2010) reveal that at certain universities in the UK and India, the authorities usually allocated international students to specific residences. The same trend was observed by Koehler and Skvoretz (2010) at an American university, where incoming black students were allocated to residences that already had a high percentage of black students. They attributed this lack of integration to the preferences of black students. Similarly, Dunne (2009) found that at an Irish university local students requested that their international counterparts lived in separate residences; a move which limited interaction between them. The same pattern of segregation was observed in dining halls and other social settings (Brown 2009).

Various studies show that students segregate themselves according to race and ethnicity (Lewis 2000; Smith and Moore 2000; Antonio 2001; Villalpando 2003; Li 2008; Stearns et al. 2009; Koehler and Skvoret 2010). Smith and Moore (2000) found that segregation occurred even when the opportunity for interracial contact in the form of allocating students to tables with their housemates in the dining halls had been created. Some black students perceived their time in the dining hall as an opportunity to 
bond and interact with other black students. They thus left their allocated tables and joined the table referred to as the black table. According to Smith and Moore (2000) black students form their own social groups to deal with alienation and hostility from the larger campus community.

In the South African context, apartheid laws formalised segregation which put some constraint on contact between people of different races (Anderson 2003; Greyling 2007; Finchiles$\mathrm{cu}$ and Tredoux 2010). When universities decided to accommodate all students they provided separate accommodation according to race (Maylam 2005; Perez and London 2004; Greyling 2007; Kurain 2008; Luescher 2009). The few black students who secured admission to predominantly white universities were prohibited from socialising with their white classmates (Cross and Johnson 2008; Goga 2008; Luescher 2009), barred from joining student societies and could not participate in extramural activities (King 2001).

Resistance to integration of university residences in post-apartheid South Africa was also evident (Durrheim et al. 2004; Southern 2008). Student organisations like the Freedom Front Plus described desegregation of student residences as forced integration and equated it with discrimination (Marais and de Wet 2009; van der Merwe 2009). Studies showed that some students used language and cultural preferences as excuses to dispute integration (Walker 2005; Flusk 2008; Southern 2008). White students perceived the integration of residences as an infringement of residence culture that was shared with their parents and grandparents (De Waal 2011). Jansen (2009) gives a detailed account of racial tensions at the University of Pretoria (UP). He argues that living together in the residences causes more racial tension than learning together in the classroom. In what Jansen (2009) calls "bitter knowledge" some high schools that serve the white Afrikaans-speaking population indoctrinate students with knowledge and ideas that make it difficult for them to adjust to racial diversity at UP residences. At UP the tension was not only between black and white students but it was also between English and Afrikaans-speaking students. Afrikaans-speaking students treated Black and English students with contempt and they were provoked when they did not ob- serve Afrikaans traditions. Even though students at UP lived in the same residences some of the residences had separate living arrangements, separate club houses and separate television sets. Some residences still retained the symbols and statues of Afrikaner pride in their hallways (Jansen 2009).

\section{The Nature of Institutional Culture}

Like most institutions, the character of university residences is also hinged on the phenomenon of culture. "Culture is historical and specific, it is both a product and a process and it reflects the way social groups are organised in society" (CHE 2010: 40). Focusing specifically on institutional culture in places of higher learning, the White Paper 3 recommends that universities should place emphasis on the importance of advancing the cultivation of institutional cultures which represent values and promote behaviour which is intended to unify, reconcile, build respect for difference and also promote the common good (DoE 1997). According to CHE (2010, 2016), institutional culture entails sharing of thoughts, actions and norms by members of a group. Understanding institutional culture can assist in explaining why students at universities do what they do and the way they do it. In this regard authorities are assisted in approaching crisis situations as they will be aware of what motivates and drives their students. South African universities should promote a campus environment which is responsive to racial and cultural diversity (DoE 1997). This directive emanated from the fact that the institutional culture at South African universities was still characterised by alienating experiences (CHE 2010, 2016).

\section{The Concept of Diversity}

Like other national systems the Ministry of higher education in South Africa is concerned with diversity (CHE 2000, 2016). Diversity is defined as "ways in which institutions seek to integrate and manage those individuals and groups not fully represented with them" (Thaver 2009: 406). According to the CHE report (2000, 2016) institutions of higher education are required to demonstrate diversity in a variety of programmes that they offer, in their teaching and research competencies, in their human and physical assets, in the credentials of their staff and 
so forth. It is further indicated that institutions of higher learning in South Africa are mandated to defend the progression of democracy which is related to promoting good citizenship (CHE 2000, 2016). In his definition of diversity Thaver (2009) attests that the process of diversity seeks to integrate individuals. To this effect some studies contend that it becomes a problem if the inclusion of people in programmes directs them to their incorporation in ways that subject them to existing standings (Sayed et al. 2003). Catering for diverse groups does not mean that institutions of learning should create access without recognising the differences of the groups included (Sayed et al. 2003; CHE 2016). Sayed et al. (2003) warns against the practice of 'window dressing' during which institutions respond because there is a need for change without understanding the necessity to transform the institutions from within in order to cater for the different groups. Institutions that are unresponsive to managing diversity within their territory tend to promote assimilation of incoming groups so that they adapt to existing norms (Sayed et al. 2003; CHE 2016).

Professionals in student affairs have the responsibility to encourage students to embrace diversity and accept differences between them (Bleiberg 2003). This can be done through ensuring that the policies of a university are consistent with the diverse nature of the institution's population. Students who seek accommodation in university residences are from different racial, ethnic and/or religious backgrounds. Thus it is the responsibility of the university to encourage students to form relationships and to learn from each other (Bleiberg 2003; CHE 2016). Efforts at embracing diversity in South African university residences are often met with intense resistance from students who are still trapped in extreme racial worlds. However, there are instances in which institutions are managing issues of diversity and inequality to the extent that it might be possible to change the institutional culture to reflect a more inclusive paradigm (Nkomo et al. 2009; CHE 2016). In light of the above arguments it becomes apparent that institutions that embrace diversity will observe practices that are consistent with human rights; ensure equality among their population and educate their people to live together irrespective of differences (Jansen 2009; CHE 2016).

\section{Theoretical Moorings}

The conceptualization of this study is ingrained in critical race theory and cosmopolitanism. Donnor (2003: 233) defines critical race theory as a "contemporary theoretical framework that critiques the dominant white hegemonic discourse and power, analyses social disparities between races, and challenges popular construction and employment of race, racism and power". Yosso (2005) affirms that CRT is a theoretical and analytical framework that is aimed at disputing how race and racism influence arrangements, traditions and discourse in education. CRT is considered a significant instrument for 'reconstruction', 'construction', and 'deconstruction' (Ladson-Billings 1998). It has the potential to advance reconstruction of human agency, to deconstruct systems of domination and to construct impartial and power relations that are fair within the society (Ladson-Billings 1998). Five tenets are highlighted in the CRT namely, the centrality of race and racism and intersectionality with other forms of subordination; challenging dominant ideology; a commitment to social justice; an emphasis on experiential knowledge, and the importance of interdisciplinary approaches (Smith-Maddox and Solorzano 2002; McDowell and Jeris 2004; Yosso 2005; Pascale 2008).

The second theoretical framework is cosmopolitanism. Proponents of cosmopolitanism assume that this theory has a legal and a moral stand point (Pogge 1992; Beck and Sznaider 2006). Legal implications of cosmopolitanism depart from the notion that all people are citizens of the world and should have comparable equal rights and duties. Whereas the moral implication of cosmopolitanism maintains that all individuals stand in certain moral relations to one another and are therefore required to respect one another (Pogge 1992). Institutional cosmopolitanism becomes relevant when dealing with ways of managing aspects of diversity (Yegenoglu 2005; Beck and Sznaider 2006; Hansen 2009; Vertovec 2010; Modood 2011). In this regard an institution is aware that a new form of political legitimacy has to be constructed, which will substitute different forms of fundamentalism and exclusivism (Kaldor 2003). Establishments must promote human equality, appreciate difference and celebrate diversity (Kaldor 2003). The relevance of cosmopolitanism in this study 
is that it is ingrained in the ideology that there should be openness to cultural diversity, a practical relation to a plurality of cultures and a tendency to engage with others (Noble 2009).

\section{RESEARCH METHODOLOGY}

This study was inspired by the methodology of portraiture which is rooted in the assumption that there are stories of goodness in schools and these stories can also be evident in other contexts (Lawrence-Lightfoot 1986). As a way of contributing to stories of goodness portraiture methods are used to study successful institutions. However these methods do acknowledge that expression of goodness is also tainted by imperfections. "In the search for goodness, it is essential to look within the particular setting that offers unique constraints, inhibitions and opportunities for its expression" (LawrenceLightfoot 1986: 14). Portraiture gives the researcher an opportunity to intentionally choose to explore the strength of the phenomenon under inquiry and the way in which it is approached and managed (Vandeyar and Jansen 2008).

The research design was qualitative in nature and a case study approach was used. The case under study was EquityRes at UU. EquityRes is an integrated student residence at Urban University. This residence was chosen because of its distinctiveness from other residences with regard to its balance in racial composition and unique living program. EquityRes was established in 2008 to meet the needs of students in relation to accommodation. This research site was selected because it fit the description of an exemplary constituent. Purposeful sampling was employed in order to select a sample that could provide rich data (Maxwell 2008). We sampled a unit of senior students who in our opinion had in-depth experience of the phenomenon under study and had already acquired a wealth of information about the case. In addition, they had the ability to effectively express their experiences (Ponterotto and Grieger 2007). This study's sample comprised a group of eight female students from one unit; four black and four white females. What was exceptional about this unit was that three participants were part of the residence management and this provided an opportunity to gain a managerial perspective. Interviewing the head of the residence as a participant in this study also enabled us to elicit infor- mation on the policies and history of the case under study (Marshall and Rossmann 2011).

The main method of data collection was semistructured interviews. The duration of each interview was approximately 60 minutes. In addition, documents related to the research site were analysed, the physical setting of the site was also observed and field notes were kept. The study comprised of three phases of semi-structured interviews namely, interviews with the residence management; interviews with the student participants and follow-up interviews. Followup interviews provided the opportunity for member checking and adding of information. Data capture occurred in 2012. Data was analysed using content analysis methods.

\section{RESULTS}

\section{So How Did The Institutional Culture at EquityRes Promote Interaction of Culturally Diverse Students?}

\section{Design of Living Space at EquityRes}

EquityRes which was situated in one of South Africa's big cities boasted infrastructures that were very different from traditional university residences. The living spaces at EquityRes were specifically designed to promote interracial and intercultural interaction. The residence had ten distinct blocks of four floors each. Each floor had two units and each unit had eight bedrooms, a communal bathroom, toilet facilities, a kitchen and a living space. The residence itself was co-ed but each unit was either occupied by males or females. Six hundred and forty students were accommodated at this residence. Three hundred and twenty were males and three hundred and twenty were females. Each unit comprised of four White and four Black students. The communal nature of each unit prompted students from diverse backgrounds to share living spaces and facilities.

Students came to EquityRes with varying preconceived perceptions, yet they began to relate and depend on each other to a certain extent. Initially, the manner in which students approached social interactions was determined by their level of exposure to racial others prior to coming to EquityRes. Mercy (black female) did not know how to handle her new association with white people on her arrival at EquityRes. 
Initially she preferred only to interact with black girls.

... growing up I was never really around other races except black. Where we lived in Nokaneng there is a lot of black people. So then when you are walking around you see one white person it's like okay, I don't really know how to approach this person, even though they are just human beings. So when I was able to drop that and just try and break through my comfort zone, I found that it was all in my head.

Staying at EquityRes helped Kgadi (black female) to work through her stereotypes. She acknowledged that being in close proximity with white people caused her to begin thinking about her own prejudices.

I thought that they were all the same. They were racist. They all think that they are better, but by engaging with them they have changed my perception. I don't think that they are better. They are just normal people and I used to think they all looked at black people as one thing. They actually see you as an individual. Like these girls notice when I change my hair, they always notice. I thought they just see "she braided".

Melisa (white female) indicated that she did not have issues with interracial interactions. Her encounters with black people in secondary school helped her to be comfortable when exposed to people from different cultures at EquityRes,

It really doesn't bother me because I was in a choir, for uhm... for five years there were some blacks and Indians as well. So I am used to like being in a bus, sharing a bathroom or chilling together and it really doesn't bother me at all.

The kitchen area provided a favourable platform for social interaction particularly in the evenings when students had to prepare their meals. They were also afforded the opportunity to talk about their frustrations and challenges and to learn about each other's cultures. Mercy recounts one of her memories

One of the white girls was beginning to cook so I was just looking at what she was cooking because it was different. I was like "Oh tell me about this". And there was another girl who was baking. I was like oh... you baking chocolate cake. Then she is like "Yes, would you like a piece?" So, ja we just got to exchange.

Joy (white female) also cherished the time she spent in the kitchen.
Uhm ... I know the thing that I enjoy most is just when ... I know it happens most in the kitchen, when everyone is around in the kitchen and that kind of thing. We are all talking and laughing and all joking around. I really enjoy that. It's fun. That's my favourite part of it.

For Elise, (white female) moments spent in the kitchen provided a homely atmosphere which was more like 'a home away from home'. She described how she valued the opportunity of interacting with her unit mates.

I do struggle because I don't get to see my parents a lot because I live far away from here. But we interact quite a bit in the kitchen when we are all cooking supper and stuff. I enjoy that. You don't feel like sitting in a room staring at four walls. Like... you have people of different experiences and stuff. It's nice to speak to everyone at the end of the day, because none of us is studying the same thing. So it's like at home you are not doing the same thing as everyone during the day. When you come home you all have different things to talk about. It's nice; it's like family that way.

Kgadi detailed what she discovered about her white housemates,

And like you know sitting with them, they are so interested in even learning about us. And they will ask you, where are you staying? Like you know we have a lot of similarities. Like now we all stay in the suburbs whatever, but they are interested in like where I used to stay. They even ask us to plait their hair, how much does that cost, they are very interested.

Students staying at EquityRes learnt to recognise and appreciate their differences.

...like we always joke about the hair thing." You guys are lucky you don't have to plait your hair." They go like "But I wish I had black hair so that I can do something else. I am always doing the same thing. The race thing only comes up as a joke or something.

The physical setup in the units allowed students to have sufficient social interactions. Participants interpreted the environment to be conducive enough to promote a sense of belonging. Most of them indicated that being able to interact with others made their unit feel like home. Some of the participants were able to deal with their prejudices and stereotypes.

\section{Management Style}

The operational dynamics of EquityRes was aimed at creating a residence that functioned 
differently from conventional university residences. Mr Peter Banda was appointed as the head of the Residence. Mr Banda was tasked with implementing a residence program that was different from other conventional residences. He fondly reminisced how he and members of the residence management team ventured to establish a new management style to create a residence that looked and operated differently.

So what we said right from the start is that we will clearly need to understand what is going to be the underpinning philosophy of the residence that will drive the human part of the residence, because we can't allow it to become like the traditional residences.

Their first priority was to change the character and residence culture at EquityRes. Still working within the vision of the university in relation to the new residence they decided that it would be academically-oriented. It would cater for students who are serious about their studies; the activities will be less structured and students will live in a communal type of environment. They solicited the services of the Ethics Department at the university to derive a code of conduct that emphasised respect for the environment, no sexism, no racism, no criminality, respect for rules and working towards becoming well-rounded citizens of South Africa. The code of conduct became the sphere of influence which gave direction to how the students were to live. Hence, he indicated

And what we then decided is we need to move from a very rule-driven kind of residence, to where the code of conduct should be what directs how we do things at EquityRes. And not we do things because of the rules, but we do things because of the code that we live by.

Unlike traditional residences that has a House Committee; EquityRes was managed by the Residence Management Committee. The management composition at EquityRes went beyond the standard patterns of power that were determined by unequal quota systems in some residences. The first student component of the Residence Management Committee was identified through interviews. The group that was chosen comprised multiracial male and female students who did not receive any privileges because of the colour of their skin. Students became part of formulating the vision, the slogan and the rules within the framework of the university. A 'bottom-up' rather than 'top-down' approach was adopted. Rules and practices that were introduced by residents were aligned with the vision, the slogan and the code of conduct that they had previously developed. In developing these rules, students adhered to the principle of cosmopolitanism that advocates a person's responsibility to refrain from violating other people's human rights (Pogge 1992). Mr Banda described EquityRes as a place of freedom that was qualified by responsibility

If you understand the freedom that we allow you in this place you will be amazed at how you can grow and become greater than you have ever thought. If you however can't handle this freedom in a responsible way you are not welcome here.

An orientation programme was developed by the Residence Management Committee aimed at creating an inclusive environment and empowering first year students. At EquityRes every person's voice counted. Seniority was not used to suppress others' viewpoints.

We also understood that we need to change the so-called orientation programme for first years, because in most residences - the traditional type of residences- the focus is on intimidating first years and inducting them into the tradition of that residence.

A series of workshops were conducted during the orientation programme aimed at understanding diversity and stereotyping; respect for the environment and inculcating life skills that would enable students to work with people from diverse racial, cultural and language backgrounds. Mr Banda and his team encouraged the students to live as a community and to respect each other.

So we started to build and we became stronger and stronger in the establishment of our culture. For example, the fact that we need to greet one another is a conscious thing that we constantly try to communicate to people.

\section{Social and Cultural Activities}

Unlike traditional residences, EquityRes did not participate in traditionally organised sport, cultural or other formalised activities. Traditional residences at Urban University were steeped in long-standing traditions that focused on challenging each other in sport, cultural and social activities. These activities were fiercely competitive in nature. EquityRes acknowledged not 
only the changing demographics of students but also addressed the changing needs and social contexts within which students found themselves

Modern students in general want to be more independent, they want be part of the residence environment that allows more independence and that may be less structured. It is more communal in nature and does not have this excessive focus on competitiveness ( $M r$ Banda).

Activities at EquityRes were initiated and managed by students. Residents attended social activities of their own free will. Social activities were also seen as an opportunity to develop friendships and to have fun. Because these activities were not imposed on students they tended to have found some enjoyment and voluntarily participated in these activities.

The fact is that when the people do plan something and you participate, it's really fun. So in EquityRes if you want to do something or if you want -to have fun, if you want to meet people and if you want to socially interact with people you have to come out by yourself... Instead of in other places where they tell you do this and do that and you kind of resist because you are being forced sometimes (Kate).

The influence of Mr Banda also made a mark on how students conducted social events at EquityRes. He promoted cultural activities that advocated racial inclusivity. Measures were put in place to curb racial or cultural bias at all events. Opportunities were given to students to initiate and advertise cultural events. In order to limit the possibility of a particular racial group monopolising social events Mr Banda ensured that the list of people associated with these events was balanced in terms of black and white participation in the event. He recounted his reaction to a list of participants that was racially uneven:

Change your advertisement, if it is not an inclusive function it is not going happen. Because we will not perpetuate stereotypes that we will have a white function and a black function. It doesn't work that way. If we don't have an inclusive function we don't have a function.

In this way cultural hegemony was deterred at EquityRes. It was important for all racial groups to be accommodated during social and cultural events. The music playlist catered for various genres popular among South African university students. Mr Banda insisted that the list should include among others kwaito, boeremusiek, English pop music, rock music and $\mathrm{R} n \mathrm{~B}$.
Mercy fondly talked about how the intervention by Mr Banda to incorporate the playlist improved the students' approach to the social events.

... you can see people were gel-ling. Ja they were gel-ling so it worked out. I think we have learnt from the past. Like especially Mr Banda was trying to... this is what he was trying to instil. He was trying to... like uhm target the social events because he had noticed differences. It has, it has worked out.

Similar sentiments were expressed by Kgadi:

In our socials... actually Mr Banda tells us that "guys you should find ways to accommodate everyone". So the social event that we had ...we opened... we started off playing white music it was so nice, the vibe was so nice, then when we started playing house music even the white people were dancing to house music because it was so integrated. There was no segregation, just all of us dancing together.

Social events did not only serve to entertain students, it also helped students to appreciate diverse cultures. At the beginning of the year students participated in the dance and playlist competition. They taught each other how to dance to different kinds of music. An ordinary moment like teaching each other moves on the dance floor enabled some students to cross the bridge that separated them in terms of their music preferences. Mercy recalled her exposure to Afrikaans music and how she learnt to dance to the sokkie sokkie.

Like when my friend and I went and they started playing sokkie sokkie, so we were like let's try it and see and then one of the guys came and said "let me show you how to do it. It was fun, it was really fun.

\section{DISCUSSION}

Several findings from this study reveal that, what an institution does in order to provide conditions that promote interactions of diverse students, will determine the extent to which students will actualize their interactions.

First, UU took cognisance of the change in its student demographics and conducted research in order to understand how best to deal with the new situation. This move by the university to examine its existing structures concurs with the legal implications of cosmopolitanism which views all people as citizens of the 
world who should have comparable equal rights and duties. It also depicts an attempt by UU to acknowledge the centrality of race and racism and its inter-sectionality with other forms of subordination and was aimed at disputing how race and racism influence arrangements, traditions and discourse in education (CHE 2016). Further, it concurs with the tenets of CRT, which proposes that institutions must understand that historically they were tainted by deficit theorising (Yosso 2002). In so doing, UU attempted to “critique the dominant white hegemonic discourse and power, analyses social disparities between races, and challenges popular construction and employment of race, racism and power" (Donnor 2003: 233; HESA 2014).

Emphasis was also placed on experiential knowledge, which is another tenet of CRT. Gurin et al. (2004) argue that the manner in which the institution structures its resources and policies has to create opportunities that will help students experience genuine racial integration which will encourage students to interact in meaningful ways (Jansen 2015; CHE 2016). UU's acknowledgement and attempt to cater for diversity within its residence aligns with the theory of cosmopolitanism which argues that individuals intersect with people who may be doing things differently which require them to cooperate and acknowledge the existence of the other (Waldron 2000). Therefore, by listening to the voices of the current student demographics, the university was able to gauge the success of its transformation policies, and whether both black and white students experience their environment as equitable, integrated and non-discriminatory (Durheim et al. 2004; HESA 2014). This also echoes the argument forwarded by Gurin et al. (2004) when they indicate that it is important that institutions go beyond increasing enrolment of previously disadvantaged groups because numerical diversity does not guarantee interaction between diverse groups on campus (Baloyi and Isaacs 2015).

Second, EquityRes offered facilities and practices that were different from the mainstream residences of the university. Physical facilities were structured in such a way that they not only encouraged integration of diverse students but promoted human equality and an appreciation of difference (Jansen 2015). It would seem that the commitment of UU to social justice had the potential to advance the reconstruction of hu- man agency, to deconstruct systems of domination and to construct impartial and power relations that are fair within the society. In accordance with the tenets of cosmopolitanism the residence provided a heterogeneous space in which a group of culturally diverse students had to learn to navigate their everyday activities (Yeoh 2004; CHE 2016). Instead of long corridors that detached the students from each other, EquityRes boasted a communal arrangement that encouraged students to interact and to stand in certain moral relations to each another. Facilities were arranged in such a way that they promoted social interactions among diverse students (Braxton and McClendon 2002). Bleiberg (2003) argues that students who seek accommodation at university residences are from different racial, ethnic or religious backgrounds and it is the responsibility of the university to encourage them to form relationships and to learn from each other. The design of the living space at EquityRes adequately fulfilled this responsibility.

Third, the placement policy determining room allocation at EquityRes was aimed at establishing racially mixed units where each unit would comprise four black and four white students. This equation in the student body at EquityRes eliminated what CRT refers to as 'subordinated position of minority’ (Ladson-Billings and Tate 1995). By implementing policies that are nondiscriminatory EquityRes created the potential to reduce racial discrimination and promote intergroup contact (Jansen 2015). It would seem that this was an intentional attempt to challenge the predominant white hegemonic culture and to engage with power relations. CRT indicates that service providers who are working towards creating inclusive programmes should start by acknowledging that race and racism which influence arrangements, traditions and discourse in education should be challenged in order to avoid any form of subordination (Villapando 2004; Quintal 2015). By explicitly indicating that student placement was to be confined within the four/four mix in terms of black and white students, the institution deterred the possibility of self-segregation at EquityRes. This act of utilising race to determine room allocation was not only a commitment to social justice efforts but an indication of the deviation from what CRT refers to as the colour-blind ideology which proclaims all students as the same (Evans 2007). It represented openness to cultural diversity, a 
practical relation to a plurality of cultures and a tendency to engage with others.

Fourth, Mr Banda and his team displayed leadership qualities that were based on transformation and emancipation. Institutional cosmopolitanism becomes relevant when dealing with ways of managing aspects of diversity (CHE 2016). EquityRes shifted from a very rule-driven system to a voluntary participatory structure. First, in its commitment to social justice efforts, the university developed a code of conduct which was aimed at guiding the students into becoming well-rounded global citizens. It set out to advance the reconstruction of human agency, to deconstruct systems of domination and to construct impartial and power relations that are fair within South African society. This attempt is aligned with the moral implications of cosmopolitanism, which encourages the experience and practice of world citizenship, where other people are recognised as fellow human beings (Pieterse 2006). Second, together with some of the students, the residence management decided on the vision of the residence and then the students developed the slogan. Third, they tailored the rules that were within the framework of the university residence rules but were also aligned with the code of conduct, the slogan and the vision of EquityRes. These initiatives are supported by CRT's call for interdisciplinary approaches and by Braxton and McCledon (2002) who argue that managers should apply methods or approaches that guarantee efficient communication of rules and regulations, and also enforce them in a fair manner (Jansen 2015).

Fifth, voices of the participants in this study revealed that both first-year and senior students had equal status. Among others this is attributed to the orientation programme that did not focus on intimidating first years or discriminating against them. Emphasising equality is aligned with the legal and moral standpoints of cosmopolitanism which advocates that all people are citizens of the world and should have comparable equal rights and duties and all persons are required to respect one another as fellow citizens (Pogge 1992; HESA 2014). It is also aligned with CRT which recognizes multiple layers of oppression and discrimination (Solorzano and Bernal 2001) and allows managers at universities to admit that their initiatives are motivated by the desire to eliminate all forms of subordination including racism, classism and sexism in higher education (Villalpando 2004). The orientation programme at EquityRes was aimed at empowering young people who were from diverse communities to interact with racial others. The programme included a workshop on understanding diversity and stereotypes and served towards fulfilling the vision and the code of conduct informing activities at EquityRes. A similar position is emphasised by Braxton and McCledon (2002) who argue that orientation programmes should avail opportunities for new students to socially interact with their peers. At EquityRes student orientation as an institutional scheme was strengthened by the constant emphasis on equality and social justice efforts aimed at deconstructing systems of domination and constructing impartial and fair power relations (Butler-Adams 2015).

EquityRes designed demographic inclusions which introduced a racial character that was distinct from other residences at UU. The dominant construct that was used to transform the demographic character of EquityRes was that of race. The centrality of race and racism and its intersectionality with other forms of subordination was aimed at disputing how race and racism influence arrangements, traditions and discourse in education. The residence provided living spaces where neither race was outnumbered and consequently offered less if no opportunity to recreate dominant groups. As a multicultural institution EquityRes belonged equally to its residents and none of the cultural groups were expected to forsake their culture or identity (Jansen 2016). All cultural groups felt a sense of belonging and feeling at home at EquityRes. An attempt to combat discrimination and accommodate diversity was made by promoting diversity and inclusion (Kymlicka 2003; Baloyi and Isaacs 2015)) not only in the design of the living space but also in the management style and cultural and social activities of EquityRes.

\section{CONCLUSION}

It is evident that EquityRes was not like any of the other residences at UU. EquityRes was intentionally designed to break the shackles of apartheid ideology that may have been transmitted through 'knowledge in the blood' which entraps young minds in extreme racial worlds and continues to perpetuate the vicious cycle of discrimination. The architects of the physical 
buildings and landscape and the architects of the residential culture and climate of EquityRes were acutely aware of the fact that a new form of political legitimacy had to be constructed, which substituted different forms of fundamentalism and exclusivism that were still prevalent in other residences at UU. However, this challenge did not deter them from their personal mission of attempting to promote human equality, appreciate difference and celebrate diversity. EquityRes proactively set out to instil openness to cultural diversity, endorse a practical relation to a plurality of cultures and encourage engagement between diverse groups. In so doing it not only advocated and advanced the reconstruction of human agency but, deconstructed and challenged traditional systems of domination and attempted to construct power relations that were just and equitable. Transformation policies that were developed by EquityRes recognised the significance of the construct of race and were intent on curbing racial and cultural discrimination and embracing diversity. These polices were enacted in the lived experiences of diverse residents and created opportunities for intercultural contact and meaningful interaction. EquityRes is a proud beacon of hope and social justice, and a shining example of "Be the change you want to see”.

\section{RECOMMENDATIONS}

This study therefore recommends that universities strive to create an inclusive environment that advocates for equality and human rights; where all students can feel a sense of belonging and feeling at home and can contribute, excel and achieve their full potential. In so doing, students' desire to interact across race and culture will be enhanced. Language, culture and colour should not be used as commodities to award advantage, but should be seen as assets that can contribute to the global pool of knowledge and our common humanity.

\section{REFERENCES}

Anderson GM 2003. Racial identity, the apartheid state, and limit of political mobilisation and democratic reform in South Africa: The case of the University of the Western Cape. Identity: An International Journal of Theory and Research, 3(1): 29-52.

Antonio AL 2001. The role of interracial interaction in the development of leadership skills and cultural knowledge and understanding. Research in Higher Education, 42(5): 593-617.

Baloyi B, Isaacs G 2015. South Africa's 'Fees Must Fall' Protests Are About More Than Tuition Costs. From<http://edition.cnn.com/2015/10/27/africa/ fees-must-fall-student-protest-south-africa-explainer/> (Retrieved on 28 January 2016).

Beck U, Sznaider N 2006. Unpacking cosmopolitanism for the social sciences: A research agenda. The British Journal of Sociology, 57(1): 1-23.

Bleiberg S 2003. A case for mixed-sex university housing policies. Journal of College and University Student Housing, 32(2): 3-9.

Bot M 1985. Black student resistance to segregated universities. Indicator SA, 3(2): 12-15.

Braxton JM, McCledon SA 2002. The fostering of social integration and retention through institutional practice. Journal of College Student Retention, 3(1): 57-71.

Breaux RM 2002. "Maintaining a home for girls": The IOWA federation for colored women's clubs at the University of IOWA, 1919-1950. The Journal of American History, 87: 236-255.

Brown L 2009. An ethnographic study of the friendship patterns of international students in England: An attempt to create home through conational interaction. International Journal of Educational Research, 48: 184-193.

Butler-Adams J 2015. Is the Decline of South African Universities Looming? South African Journal of Science, lll: 11/12, November/December, Article no. 0132, pp.1-2. From<http://dx.doi.org/10.17159/ sajs.2015/a 0132> (Retrieved on 28 January 2016).

Buttny R 1999. Discursive constructions of racial boundaries and self-segregation on campus. Journal of Psychology, 18(3): 247-268.

CHE 2000. Towards A New Higher Education Landscape: Meeting the Equity, Quality and Social Development Imperatives of South Africa in the $21^{\text {st }}$ Century. Policy Report. Pretoria: Council on Higher Education.

CHE 2010. Access and Throughput in South African Higher Education: Three Case Studies. Higher Education Monitor (No. 9 March). Policy Report. Pretoria: Council on Higher Education.

CHE 2016. South African Higher Education Reviewed. Two Decades of Democracy. Policy Report. Pretoria: Council on Higher Education.

Cross M 2004. Institutionalising campus diversity in South African higher education: Review of diversity scholarship and diversity education. Higher Education, 47: 387-410.

Cross M, Johnson B 2008. Establishing a space of dialogue possibilities: Student experience and meaning at the University of Witwatersrand. South African Journal of Higher Education, 22(2): 302-321.

De Waal M 2011. The Beautiful Mind of Jonathan Jansen. From <http://www.dailymaverick.co.za>.

Department of Education 1997. White Paper 3: A Programme for Higher Education. Pretoria, South Africa: DOE.

Donnor JK 2003. Learning from black folk(s): Race, technology, and society. In: Gloria Ladson- Billings (Ed.): Critical Race Theory Perspectives on Social 
Studies: The Profession, Policies, and Curriculum. Greenwich, CT: Information Age Publishing, pp. 231-246.

Douglas KB 1998. Impressions: African American firstyear students' perceptions of a predominantly white university. The Journal of Negro Education, 67(4): 416-431.

Dunne C 2009. Host students' perspectives of intercultural contact in an Irish university. Journal of Studies in International Education, 13(2): 222-239.

Durrheim K, Trotter K, Piper L, Manicon D 2004. From exclusion to informal segregation: The limits to racial transformation at the University of Natal. Social Dynamics, 30(1): 141-169.

Evans AE 2007. Changing faces: Suburban school response to demographic change. Education and Urban Society, 39(3): 315-348.

Finchilescu G, Tredoux C 2010. The changing landscape of intergroup relations in South Africa. Journal of Social Issues, 66(2): 223-236.

Fisher BJ, Hartmann DJ 1995. The impact of race on social experience of college students at a predominantly white university. Journal of Black Studies, 26(2): 117-133.

Flusk LM 2008. Factors Influencing Interracial Mixing among University Students. PhD Thesis. Alice, South Africa: University of Fort Hare.

Goga S 2008. The Silencing of Race at Rhodes: Ritual and Anti-Politics on a Post-Apartheid Campus. PhD Thesis. Grahamstown, South Africa: Rhodes University.

Greyling SA 2007. Rhodes University during the Segregation and Apartheid Eras, 1933-1990. MEd Thesis. Grahamstown, South Africa: Rhodes University.

Gurin P, Nagda BA, Lopez GE 2004. The benefit of diversity in education for democratic citizenship. Journal of Social Issues, 60(1): 17-34.

Hansen DT 2009. Chasing butterflies without a net: Interpreting cosmopolitanism. Studies in Philosophy and Education, 29: 151-166.

HESA 2014. South African Higher Education in the $20^{\text {th }}$ Year of Democracy: Contexts, Achievements and Key Challenges. HESA Report Presented to the Portfolio Committee on Higher Education and Training. South Africa.

Jansen J 2015. Leading for Change: Race, Intimacy and Leadership on Divided University Campuses. San Francisco, USA: Jossey-Bass.

Jansen JD 2009. Knowledge in the Blood. Cape Town: UCT Press.

Kaldor M 2003. American power: From 'compelence' to cosmopolitanism? International Affairs, 79(1): 1-22.

King KL 2001. Stumbling towards racial inclusion: The story of transformation at the University of the Witwatersrand. In: RO Mabokela, KL King (Eds.): Apartheid No More: Case Studies of Southern African Universities in the Process of Transformation Westport: Bergin and Garvey, pp. 73-90.

Koehler G, Skovoretz J 2010. Residential segregation in university housing: The mathematics of preferences. Social Science Research, 39: 14-24.

Kurian HC 2008. Cross Boundaries: Using the Theory of Planned Behaviour to Explain Intention to Mix
Socially with Members of Other Race Groups. MEd Thesis. Braamfontein, Johannesburg, South Africa: University of Witwatersrand.

Kymlicka W 2003. Multicultural state and intercultural citizen. Theory and Research in Education, 1(2): 147-169.

Ladson-Billings G 1998. Just what is critical race theory and what is it doing in a nice field like education? Journal of Qualitative Studies in Education, 11(1): 7-24.

Ladson-Billings G, Tate WF 1995. Towards critical race theory of education. Teachers College Record, 97(1): 47-68

Lawrence-Lightfoot S 1986. On goodness in schools: Themes of empowerment. Peabody Journal of Education, 63(3): 9-8.

Lawrence-Lightfoot S, Davis JH 1997. Art and Science of Portraiture. San Francisco: Jossey- Bass.

Lewis AE, Chesler M, Forman TA 2000. The impact of colour blind ideologies on students of color: Intergroup relations at a predominantly white university. The Journal of Negro Education, 69(1/2): 7499.

Li J 2008. Interactions between Self-Segregation and University Housing Policy. PhD Thesis, Champaign, IL, United States: University of Illinois at UrbanaChampaign.

Luescher TM 2009. Racial desegregation and the institutionalisation of 'race' in university governance: The case of the University of Cape Town. Perspectives in Education, 27(4): 415-425.

Marais W, de Wet JC 2009. The Reitz video: Inviting outrage and/or pity? Communitas, 14: 27-42.

Marshall C, Rossmann GB 2011. Designing Qualitative Research. $5^{\text {th }}$ Edition. Los Angeles: Sage.

Maxwell JA 2008. Designing a qualitative study. In: ML Bickmanm, MD Rog (Eds.): Handbook of Applied Social Research Methods. ${ }^{\text {nd }}$ Edition. Thousand Oaks: Sage Publications, pp. 214 -227.

Maylam P 2005. Rhodes University: Colonialism, segregation and apartheid, 1904-1970. African Sociological Review, 9(1): 14-22.

McDowell T, Jeris L 2004. Talking about race using critical race theory: Recent trends in the journal of marital and family therapy. Journal of Marital and Family Therapy, 30(1): 81-94.

Mclean M 2000. Students association at a South African in higher education medical school: Implications for educators. Teaching, 5(3): 323-344.

Merriam SB 2002. Qualitative Research in Practice: Examples for Discussion and Analysis. San Francisco, CA: Jossey Bass.

Modood T 2011. Multiculturalism and integration: Struggling with confusions. In: H Mahamdallie (Ed.): Defending Multiculturalism: A Guide for the Movement. Bristol, United Kingdom: Bookmarks, pp. 61-76.

Nkomo M, Vandeyar S, Malada B, Phatlane R, Tabane $\mathrm{R}$, Phurutse M 2009. The state of pedagogy in desegregated South African schools: Peering into the classroom. In: M Nkomo, S Vandeyar (Eds.): Thinking Diversity while Building Cohesion: Transnational Dialogue on Education. Amsterdam: Rozenberg, pp. 41-62.

Noble G 2009. Everyday cosmopolitanism and the labour of intercultural community. Everyday Multiculturalism, 46-65. 
Pascale M 2008. Talking about race: Shifting the analytical paradigm. Qualitative Inquiry, 14(5): 723741.

Peacock N, Harrison N 2009. “It's so much easier to go with what's easy" "mindfulness" and the discourse between home and international students in the United Kingdom. Journal of Studies in International Education, 13(4): 487-508.

Perez G, London L 2004. Forty-five years apart confronting the legacy of racial discrimination at the University of Cape Town. South African Medical Journal, 94(9): 764-770.

Pieterse J 2006. Emancipatory cosmopolitanism: Towards agenda. Development and Change, 37(6): 1247-1257.

Pogge TW 1992. Cosmopolitanism and sovereignty. Ethics, 103: 48-75.

Ponterotto JG, Grieger I 2007. Effectively communicating qualitative research. The Counselling Psychologist, 35: 404-430.

Quintal G 2015. What You Need To Know About \#FeesMustFall. Mail and Guardian, 25 January 2016.

Reddy T 2004. Higher Education and Social Transformation: South African Case Study. Pretoria: Council on Higher Education Task Team.

Sayed Y, Soudien C, Carrim N 2003. Discourses of exclusion and inclusion in the south: Limits and possibilities. Journal of Education Change, 4: 221-248.

Smith SS, Moore MR 2000. Intra-racial diversity and relations among African-Americans: Closeness among black students at a predominantly white university. American Journal of Sociology, 106(1): 139.

Smith-Maddox R, Solorzano DG 2002. Using critical race theory, Paulo Frere's problem posing method, and case study research to confront race and racism in education. Qualitative Inquiry, 8(1): 66-84.

Solorzano DG, Bernal DB 2001. Examining transformational resistance through critical race and Latcrit theory framework: Chicana and Chicano student in an urban context. Urban Education, 36(3): 308-342.

Solorzano DG, Yosso TJ 2002a. A critical race counterstory of race, racism and affirmative action. Equity and Excellence in Education, 35(2): 155-168.

Solorzano DG, Yosso TJ 2002b. Critical race methodology: Counter-story telling as an analytical framework for education research. Qualitative Inquiry, 8(1): 23-44.

Solorzano DG 1997. Images and words that wound: Critical race theory, racial stereotyping and teacher education. Teacher Education Quarterly, (24): 519.

Southern N 2008. The Freedom front plus: An analysis of Afrikaner politics and ethnic and ethnic identity in the new South Africa. Contemporary Politics, 14(4): 463-478.

Stearns E, Buchmann C, Bonneau K 2009. Interracial friendships in the transition to college: Do birds of a feather flock together once they leave the nest? Sociology of Education, 82: 173-195.

Stevenson N 2002. Cosmopolitanism, multiculturalism and citizenship. Sociological Research Online, 7(1): 1-17.
Thaver B 2009. Diversity and research practices among academics in South African universities: Race for the market. Perspectives in Education, 27(4): 406414.

The Bill of Rights of the Constitution of the Republic of South Africa 1996. Government Gazette No. 17678.

Thornton M, Bricheno P, Iyer P, Reid I, Wankhede G, Green R 2010. Diversity and social integration on higher education campuses in India and the UK: Students and staff perspectives. Research in Postcompulsory Education, 15(2): 159-176.

Tswanya Y 2015. It Wasn't About Fees - Jonathan Jansen. From <http://www.iol.co.za/news/south-africa/western-cape/it-wasnt-about-fees-jonathanjansen-1941661> (Retrieved on 28 January 2015).

Urban University 2008. History of Urban University. Retrieved from Official University Website. History of Urban University. From <http://www.up.ac.za>. van der Merwe JC 2009. Communicative-philosophical challenges of managing a male residence at the University of the Free State. Communitas, 14: 4356.

Vandeyar S, Jansen JD 2008. Diversity High: Class, Colour, Culture, and Character in a South African High School. Lanham: University Press of America.

Vertoc S 2010. Towards post-multiculturalism? Changing communities, conditions and contexts of diversity. International Social Science Journal, 61(199): 83-95.

Villalpando O 2003. Self-segregation or self-preservation? A critical race theory and critical Latina/o theory analysis of a study of Chicana/o college students. International Journal of Qualitative in Education, 16(5): 619-646.

Villalpando O 2004. Practical considerations of critical race theory and Latino critical theory for Latino college students. New Directions for Student Services, 105: 4-50.

Waldron J 2000. What is cosmopolitanism? The Journal of Political Philosophy, 8(2): 227-243.

Walker M 2005. Race is nowhere and race is everywhere: Narratives from black and white South African university students in post-apartheid South Africa. British Journal of Sociology of Education, 26(1): 41-54.

Ward C, Masgoret A 2004. The Experiences of International Students in New Zealand: Report on the Results of the National Survey. Prepared for the Ministry of Education, Victoria, New Zealand.

Yegenoglu M 2005. Cosmopolitanism and nationalism in a globalized world. Ethnic and Racial Studies, 28(1): 103-131.

Yeoh BSA 2004. Cosmopolitan and its exclusions in Singapore. Urban Studies, 41(12): 2431-2445.

Yosso TJ 2002. Toward critical race curriculum. Equity and Excellence in Education, 35(2): 93-107.

Yosso TJ 2005. Whose culture has capital? A critical race theory discussion of community cultural wealth. Race, Ethnicity and Capital, 8(1): 69-91.

Paper received for publicaiton on May 2016

Paper accepted for publication on August 2016 